\title{
THE PERCEIVED RISK OF TERRORISM
}

SSE/EFI Working Paper Series in Business Administration No 2002:11

\author{
Lennart Sjöberg \\ Center for Risk Research \\ Stockholm School of Economics \\ Stockholm \\ Sweden
}

16 January 2004

Address

Box 6501

11383 Stockholm

Tel. +4687557234

Fax +468307225

e-mail Lennart.Sjoberg@hhs.se 


\title{
THE PERCEIVED RISK OF TERRORISM ${ }^{1}$
}

\section{Lennart Sjöberg}

\begin{abstract}
Perceived risk of terrorism was studied with a group of Swedish respondents, $\mathrm{N}=294$, response rate 71.0 percent. The over-all level of perceived risk of terrorism was low in this group (data obtained in June of 2002). Risk to others from terrorism was rated as larger than personal risk, suggesting a relatively high level of perceived possibility to protect oneself against this hazard. Women gave larger risk ratings than men did, and so did older respondents and respondents with a low level of education. However, demographics accounted for only about 5 percent of the variance of perceived risk. The Psychometric Model dimensions of Dread and New Risk were also measured. New Risk had no correlation with perceived risk, but Dread did. Other factors contributed more, however. In particular, reasons for terrorism in terms of global criminality and also perceived selfishness and greed were important, and so was a tendency towards suspicious thought patterns. Belief in competence of the perpetrators had a positive correlation with perceived risk, but a stronger effect could be discerned from seeing the perpetrators as confused and misinformed about the modern world. Perceived terrorism risk correlated strongly with items measuring the generalization of the hazard over space and time. Implications for models of risk perception are discussed.
\end{abstract}

Key words: risk perception, terrorism

\footnotetext{
${ }^{1}$ This study was supported by a grant from The Bank of Sweden Tercentary Fund.
} 


\section{Introduction}

The events of 11 September 2001 is an example of risks and hazards that have not often been studied in the current risk management and risk perception literature. The reason may be that the latter work has been motivated by policy concerns mostly related to the management of technology in modern society. Since terrorism has currently emerged as a prime topic for risk management it is an issue of urgent policy interest. The present paper is a study of terrorism in the wake of the events of 11 September 2001, partly using methodology developed in previous risk perception work. It will take as its point of departure common conceptualizations of the field, but will attempt to extend them so as to fit better to the case at hand.

The economic, social and political after-effects of 9/11 have been extremely large (Sellers, 2002). The traditional approaches to risk perception and management may be insufficient to understand them, however. A few studies of perceptions of terrorism risks have been published, but they did not go into details of the thoughts and beliefs pertinent to such perceptions (Fischhoff, Gonzalez, Small, \& Lerner, 2003; Lerner, Gonzalez, Small, \& Fischhoff, 2003; Sunstein, 2003; Viscusi \& Zeckhauser, 2003). In the present paper, and attempt is made to map beliefs behind the risk perceptions.

The Theory of Social Amplification of Risk (Kasperson, 1992; Kasperson et al., 1988; Renn, Burns, Kasperson, Kasperson, \& Slovic, 1992) states that certain kinds of hazards and accidents are especially likely to lead to widespread and strong concerns. Radiation and nuclear power hazards have an important place in the theory. They are said to be likely to cause ripple effects due to their extreme position in a postulated two-dimensional space of risk perception, summarized in the Psychometric Model. The dimensions of the model are New Risk and Dread, nuclear power being, according to research now about 25 years old, extreme in both these dimensions (Fischhoff, Slovic, Lichtenstein, Read, \& Combs, 1978). The two dimensions are said to account for most of the variance of perceived risk. However, the Psychometric Model is fairly weak when it comes to accounting for variations among individuals (Gardner \& Gould, 1989; Sjöberg, 1996, 2002a, in press-a). A common average figure of variance accounted for is 20 percent. When it comes to intra-individual variation among hazards, in contrast to the variation among individuals for a given hazard, only few studies have published pertinent data; see Marris et al. (Marris, Langford, Saunderson, \& O'Riordan, 1997) for an example. The power of the model has been found to be as low, or even lower, at that level as at the inter-individual level of analysis (Sjöberg, 2002a). The only level of analysis yielding a high explanatory power is that of averages across individuals. In the present paper, analysis is confined to inter-individual variation and an attempt is made to extend the analysis to other factors than those traditionally used in the Psychometric Paradigm.

There have been many opinion polls and a limited number other studies of the public's perception of terrorism risk since 9/11. I will discuss a sample of studies from Sweden and the USA. The results regarding perceived risk and threat obtained in October 2001 by political science researchers in Gothenburg, Sweden - the SOM Institute - with a random sample of the Swedish population (Holmberg \& Weibull, 2002) are pertinent. Terrorism was 
the most worrying threat in that study. The Gothenburg study is hard to interpret, however, because the instructions were somewhat unclear, asking "what do you yourself experience as most worrying for the future"? Is this a way of asking about personal risk or general risk?

Bennulf reported another study from the fall of 2001 in Sweden (Bennulf, 2002). This study asked about "worry" and found terrorism to rank third. All the threats and hazards were concerned with violence and various life threatening hazards, no economic risks or other social risks were mentioned. The average rating of Terrorism was 2.5 on a scale from 1 to 5 , between a "rather high" level and "a level of worry neither high nor low".

More Swedish data on terrorism were obtained by Lindkvist, Österman and Timander in the fall of 2001 (Lindkvist, Österman, \& Timander, 2002). Again, the perceived threat was quite high. Österman also found that other risks had been given lowered ratings while terrorism drastically increased. It is possible to interpret this finding as an example of a contrast effect, suggested in a previous paper to occur in the wake of a very salient and major disaster (Sjöberg \& Drottz-Sjöberg, 1991). The Eurobarometer data from the Fall of 2001 also showed a remarkably high level of fear of terrorism (European Commission, 2002), as many as 83 percent in the Swedish sample said the were "personally afraid" of terrorism.

Later data are also available, in a study by Stütz (Stütz, 2002). Telephone interviews conducted in September - October of 2002 show that the high level of perceived threat from terrorism among the Swedish public a year earlier had faded. However, another Swedish polling organization reported an unchanged high level of perceived threat from terrorism (Forskningsgruppen för Samhälls- och Informationsstudier, 2002). These data are surprising and hard to explain. One possibility is that the escalating threat of war in the fall of $2002 \mathrm{had}$ an effect on public risk perception.

It seems that the Swedish public first was quite alarmed, and then quickly became less concerned about terrorism in the 9 months that had elapsed since the attack when the present data were collected. A relatively fast tapering off of an initial strong reaction was found also in 1986-87 after the Chernobyl accident that involved Sweden more closely than the attack on the WTC.

Polls conducted in the USA (Gallup, 2002) have also shown a drop in risk perception, from a very high level of perceived risk in October 2001 to considerably less in 2002 and 2003. In the first months after the events there is even evidence of rather wide-spread stress reactions (Silver, Holman, McIntosh, Poulin, \& Gil-Rivas, 2002) - around 10 percent of the population outside New York, larger within New York (Galea et al., 2002; Schlenger et al., 2002). Psychiatric care was called for in some cases in the aftermath of a disaster of the 9/11 type (Katz, Pellegrino, Pandy, Ng, \& DeLisi, 2002). A study of adolescents found evidence for strong and generalized fear of dying after the attack (Halpern-Felsher \& Millstein, 2002).

In October 200183 percent of the respondents said a new attack within the next several weeks was very or somewhat likely. This is a very high figure, still no sign that "panic" was imminent (Durodié \& Wessely, 2002). The corresponding figure in July 2002 was 56 percent. In October 2001, 59 percent said they were worried that they or someone in their families would become victims of terrorism; in May 2002 the figure had dropped to 40 percent, a fairly normal number when the trend since 1995 is considered. See the Gallup summary report (Gillespie, 2002) for an overview of all these data and further details. 
It should also be mentioned that already in February 2002, there was a strong belief in the American public in increased airline security. Continuing work by the Gallup organization has shown a clear trend towards less worry over terrorism from 2001 to the Fall of 2002 and Winter of 2003 (Saad, 2003), only to be followed by another rise in the late summer of 2003 (The Gallup Organization, 2003). In the beginning of 2003, the level of worry ("very worried" or "somewhat worried") seemed to be elevated by some 5 percent over the level before $9 / 11$.

The methods used by polling firms to study risk perception are diverse and seldom comparable and appear not to have caught up with developments in research on risk perception. A separate discussion of that matter is warranted (Sjöberg, 2003b). Even more important, it is only rarely that attempts are made to map how people think about these issues. Only a few questions are posed, giving little or no chance at a more in-depth analysis. The present paper is an attempt to perform such an analysis, using dimensions and items fitted to the particular case at hand.

\section{Factors in the perceived risk of terrorism}

There was no previous research on factors behind risk perception of terrorism, except that possibly the Psychometric Model may have some explanatory power. Because of this, two dimensions from that model were investigated, viz.

$$
\begin{array}{ll}
! & \text { Dread } \\
! & \text { New Risk }
\end{array}
$$

Furthermore, the following classes of explanatory concepts were studied, on the basis of the current extensive discussions of the events:

! $\quad$ Reasons for riskiness of the world, in general.

! $\quad$ Characteristics of the perpetrators of the $9 / 11$ events

! Reasons and interpretations of the $9 / 11$ events

! Personality in terms of a tendency towards suspicious thought habits

The choice of concepts calls for some comments.

(1). The $9 / 11$ events reminded everyone that the world is a risky place. What are the reasons for this state of the world? What are the basic causes of hazards? The present paper explores such beliefs, and relates them to perceived risks of terrorism. The stronger the cause, the larger should the perceived risk be.

(2). In addition, the perpetrators' characteristics were taken into account. It may be suggested that the more competent they are seen to be, the larger should the perceived risk be. The more competent your enemy is, the more you fear him or her. However, competence has several aspects. One is the sheer technical competence required for carrying out an act of terrorism, another is the understanding of the terrorist that the act will bring about the desired consequences in the long run, and not to retribution or loss of popularity in his or her own camp. Both these aspects are studied here. 
(3). An attempt were also be made to investigate how the 9/11 events were construed and how these belief structures are related to risk perception. There has been a very large volume of discussion about the events in question. Some people see them as evil deeds of people with purely destructive or at least deeply misguided intentions; others see the cause of the 9/11 events in global politics and "injustice" done to some countries or religious creeds. Several items of the questionnaire devised for the present study measured conceptions of causes and intentions behind the $9 / 11$ events.

(4). Finally, the inclination to conclude from one incident that there is a grand plan behind it is common in certain thought patterns involved in beliefs that there is subversion, manipulation and secret control of citizens. It is reasonable to expect that some of the perceived risk of terrorism following $9 / 11$ can be accounted for by such an inclination. This is of course not to say that such a plan did not exist, or does not exist, but there are people with such thought patterns and they may be expected to have reacted particularly strongly to the events. In the present paper, thought patterns of subversion, manipulation and secret control are measured and related to perceived risks of terrorism. It was hypothesized that this is a one-dimensional construct, and a set of items was constructed, tailor-made to fit the needs of the current study; previous scales, such as the one published by Rawlings and Freeman (Rawlings \& Freeman, 1996) are too general.

Perceived risks were to be studies as personal and general (Sjöberg, 2003a) but also as threats to society. The latter mode is clearly called for in a study of perceived risks of terrorism.

\section{Purpose of the study}

Summing up, the purposes of the present study were:

! $\quad$ To study the level of perceived risk of terrorism

! To relate the perceived risk of terrorism to

" Dread and New Risk factors

" How pronounced the perceived reasons for "a risky world" are

" Thought patterns stressing subversion, manipulation and secret control

! To investigate the role of the perceived characteristics of the perpetrators of the events of $9 / 11$ for the perceived risk of terrorism

! To investigate the role of the belief structure regarding the events of $9 / 11$ for the perceived risk of terrorism

\section{Method}

\section{Participants}

There were three subgroups of participants. One group of 118 persons had taken part in an earlier survey study of trust and risk perception, and then indicated that they were willing to take part in another similar study. Two other groups had a similar background. In their case, the previous study was concerned with the siting of a nuclear waste repository. The first group was part of a random sample of the Swedish population at large, the other two groups were parts of random samples of the populations of two municipalities (Östhammar and 
Oskarshamn), $n=158$ and 163 , respectively. In earlier work, we have compared data on risk and trust from such samples of people who said they were willing to take part in a new study with data from random samples and found very similar results.

After one reminder and about three weeks, the response rate was 71.0 percent, when data collection was closed in the beginning of July $2002^{2}$. The total number of respondents was 294. An incentive was used; respondents were promised two lottery tickets worth SEK 50 (US\$ 5) for participation. The questionnaires were filled out in a quite complete and careful manner by most of the respondents. There were 164 men among the respondents $(56.0$ percent), 127 women and 3 who did not state their gender. Hence, the group contained somewhat too many men to be strictly representative with regard to gender. Age varied between 18 and 75+, median 50. Education was distributed as follows (percentage highest level completed):

- Nine-year compulsory school ${ }^{3}$ only: 16.0

- Vocational school: 13.8

- Two-year secondary school: 15.2

- Three-year secondary school, general: 17.0

- Three- or four year secondary school, engineering: 11.1

- University degree at the BA level: 19.4

- MA or PhD: 1.4

- Other: 5.2

The distribution of the sample with regard to education is in fairly good agreement with the population at large. The surplus of highly educated respondents was small. This fact may be surprising since surveys usually attract too many respondents with a high level of education. The present results may be due to the high response rate. The reason is probably also that the two municipalities Östhammar and Oskarshamn by themselves have populations with a lower level of education than the Swedish population. The main bias of the respondent sample is, thus, somewhat too many males and also a predominance of people living in rural areas or small towns. There is no reason to expect that these biases have affected the results to a serious extent.

\section{Questionnaire}

The questionnaire comprised 22 pages in A4 format. It is posted on the Internet (http://www.dynam_it.com/institute/) or can be obtained directly from the author. There were a total of $386^{4}$ questions, distributed as follows:

- Ratings of personal and general risk of 46 hazards; 5 of these were concerned with terrorism. These ratings were made on category scales going from 0 (no risk) to 7 (very large risk) and a DK (don't know) box were provided for each hazard in case the respondents

\footnotetext{
2. Twenty-four addresses were not usable, hence the net sample size was 415 .

${ }^{3}$. In Sweden, almost all children start school at the age of 7 , hence this group consists of respondents who had 9 years of education, with the exception of some older respondents who had less.

${ }^{4}$. Only about half of the questions were used for the present study; the remaining were concerned with risks of various technologies.
} 
wanted to abstain from rating that particular hazard. Such ratings were treated as missing data.

- Ratings of 17 threats to the Swedish society, same scales as in the risk ratings

- 8 sections of ratings of technologies, not treated in the present paper

- A section calling for explanations of reasons for risks in the world, 28 possible causes rated on a 5-step category scale from "to a very large extent" to "not at all, or extremely little". No DK category.

- A section intended for the measurement of suspicious thought patterns, 15 items rated on 5step category scales from "agree absolutely" to "disagree absolutely", with a middle category denoting hesitation. No DK category.

- A section of 47 items of statements about the attack on the WTC and 26 statements about those responsible for the attack, same scale as in the previous section

- A few questions about media habits (not reported here), background questions, assessment of the quality of the questionnaire, and judgment of the time taken to respond.

The median time taken to respond was 45 minutes. The percentages of respondents who gave a positive evaluation of the study and the questionnaire (percentage of negative assessments ${ }^{5}$ in parentheses), in various respects, were as follows:

- Meaningful study: 75.4 (3.6)

- Clearly formulated questions: 84.4 (3.9)

- Clearly formulated response alternatives: 87.2 (1.8)

- Brought up what is important in this context: $85.1(0.8)$

- Did not try to influence the answers in a certain direction: 72.8 (6.6)

- Created an interest to get more information about these topics: 20.1 (33.1)

- Did not make the respondent worried over the hazards treated: 64.4 (12.6)

- Interesting task to fill out the questionnaire: 68.0 (13.3)

- Easy to read, clear layout: 88.4 (3.8)

- Not many unnecessary questions included: 47.0 (22.3)

Hence, the assessment was quite positive although some thought there were too many questions. Rather few had been inspired to get more information about the topics, but that is a common result. Also, some had become worried which is also a common result.

\section{Scale construction}

A few of the sections contained several items that were intended to form the basis of indices to be used in the final data analysis. Scale construction is described here, since it was a methodological and preliminary step.

Thought patterns stressing subversion, manipulation and secret control. Some people are known to be very suspicious and always expect the worst (Poortinga \& Pidgeon, 2003; Rawlings \& Freeman, 1996). Terrorism is of course a reality, yet we interpret reality in various ways. Especially how we generalize from one incident to conceptions of global threats is very interesting and important for the present study. Hence, 15 items were constructed to measure such a tendency. Examples are:

\footnotetext{
5 . Positive and negative do not add to 100 because there was a also a middle category for hesitant responses.
} 
! There are many important things going on in the world that we are never informed about.

! I believe that American government agencies such as the FBI and CIA read e-mail in our country without us knowing about it.

! The authorities have ways of finding out how I voted in elections to Parliament.

The 15 items intercorrelated strongly and the alpha coefficient was 0.87 . However, 3 of the items were explicitly concerned with terrorism and would therefore have some semantic overlap with risk perception of terrorism, so they were not used in index construction. The resulting 12-item scale had an alpha of 0.86. It will be designated Suspicious Thought.

Reasons for a risky world. Twenty-eight items were suggestions for why the world is risky. Examples are:

! Conflicts between nations, ethnic groups or religions.

Corporate profit interests.

Drug abuse.

The items were factor analysed ${ }^{6}$. The structure was somewhat complex but two large and clear dimensions could be isolated: Crime and Selfishness. Crime was measured by 7 items, alpha $=0.78$, and Selfishness by 8 items, alpha $=0.79$.

Conceptions of the WTC attack and characteristics of the perpetrators. Forty-seven items measured various opinions about the WTC attack and 26 items were dealing with the characteristics of the perpetrator(s) ${ }^{7}$. Examples from the first subsection are:

! $\quad$ The attack against the WTC was part of a larger plan.

! The attack against the WTC was largely the result of religious fundamentalism.

! The attack against the WTC does not concern us in Sweden.

Examples from the second subsection are:

! Those responsible for the attack had clear goals with their action.

! Those responsible for the attack have large economic resources.

! Those responsible for the attack come from a culture very different from ours.

Factor analysis of these two sets of items (simultaneous analysis) gave four overarching factors:

${ }^{6}$. Details of this factor analysis and other factor analyses used in scale construction are posted on the web site http://www.dynam_it.com/institute.

7. To avoid biasing the respondents in one direction or the other, it was stressed that these items referred to "the person, group or organization behind the attack against the World Trade Center". 
! Perpetrators were efficient in doing what they did (12 items, alpha $=0.79)$

Perpetrators lacked understanding of the modern world ( 8 items, alpha $=0.73$ )

The attack was due to lack of justice in the world (11 items, alpha=0.86)

New attacks are imminent (10 items, alpha $=0.80)$

Finally, the Psychometric Model dimensions of Dread and New Risk were measured by two items each, which were averaged to form indices ${ }^{8}$.

\section{Results}

\section{Risk and threat to society}

In the present study, use was made both of risk (personal and general) and threat to society. As a preliminary, the relationship between these two approaches to perceived risk was investigated. The threat to society item correlated far from perfectly with the risk ratings of terrorism ( 5 hazards combined): 0.56 and 0.57 for general and personal risk, respectively. General and personal risk rating indices correlated strongly, on the other hand, 0.74 . Hence, both approaches will be used in the subsequent data analyses.

\section{Level of perceived risk of terrorism}

Sweden has been spared from the experiences of terrorism that many other countries have had. The present study shows a fairly low level of concern over terrorism; specified in the study as five different hazards, see Table 1 . Table 1 is confined to results obtained with a measure of perceived terrorism risk, obtained by selecting the five hazards in question.

\footnotetext{
${ }^{8}$. Alpha coefficients are not reported because only two items were involved.
} 


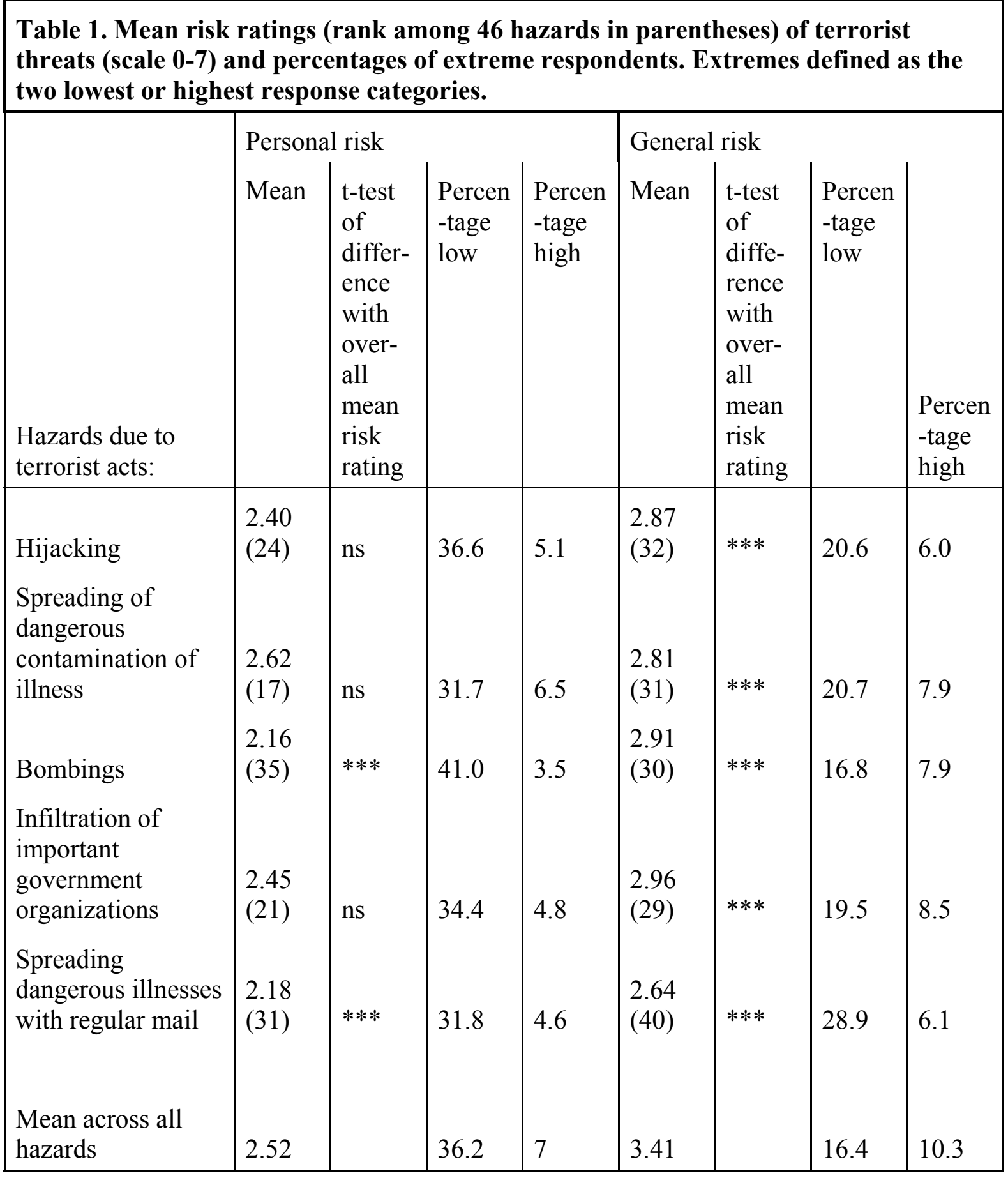

$* * * \mathrm{p}<0.0005$

The table shows the following:

! The risk ratings of the five terrorist hazards tended to be below the average of all 46 hazards. In one case, there was a somewhat higher (non-significant) than average rating of a personal risk. In several cases, the terrorist hazards were judged significantly lower than the average of other, non-terrorist, hazards. 
! Personal risk ratings were considerably lower than general risk, but relatively speaking, in a ranking of personal risks, they were higher.

! The percentage of very low risk ratings was about six times larger than the percentage of high ratings for personal risk. For general risk, the span was smaller, about 1-2. About 5-10 percent of the sample rated a very high level (two highest response categories) of terrorism risk. About 20-30 percent rated an extremely low level. Previous work has shown the same tendency for extremely high risk ratings to be considerably less common than the opposite, extremely low risk ratings (Sjöberg, submitted).

Another way to ask about risk perception is to ask about perceived threats to society. In the present study there were 17 threats, rated on the same $0-7$ scale as the risks. The mean rating for international terrorism was 3.07 , the fifteenth largest threat of 17 , i.e. a very low value, relatively speaking. The threats to society ranking highest were:

! Corporations leaving Sweden

! Lowered quality of education

! Increased economic inequality

Background data correlated with perception of the risks of terrorism. Women gave higher ratings than men did, and so did people with a lower level of education and also older respondents, see Figs. 1-3.

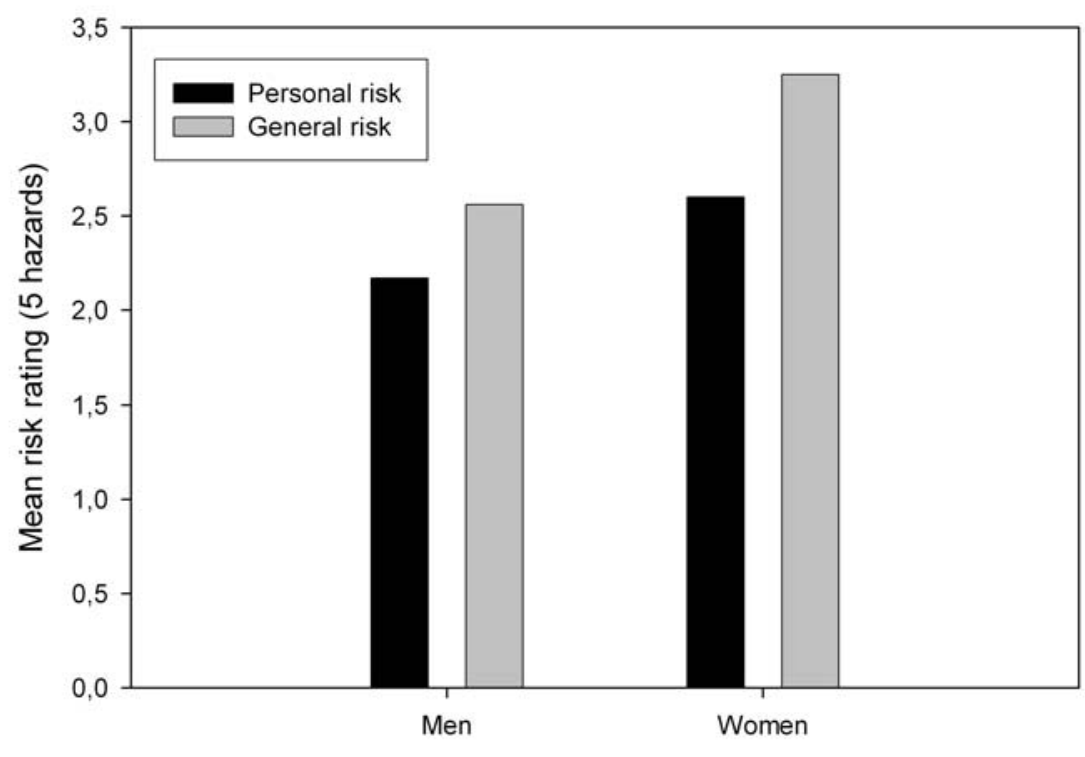

Fig. 1. Gender differences, personal and general terrorism risk 


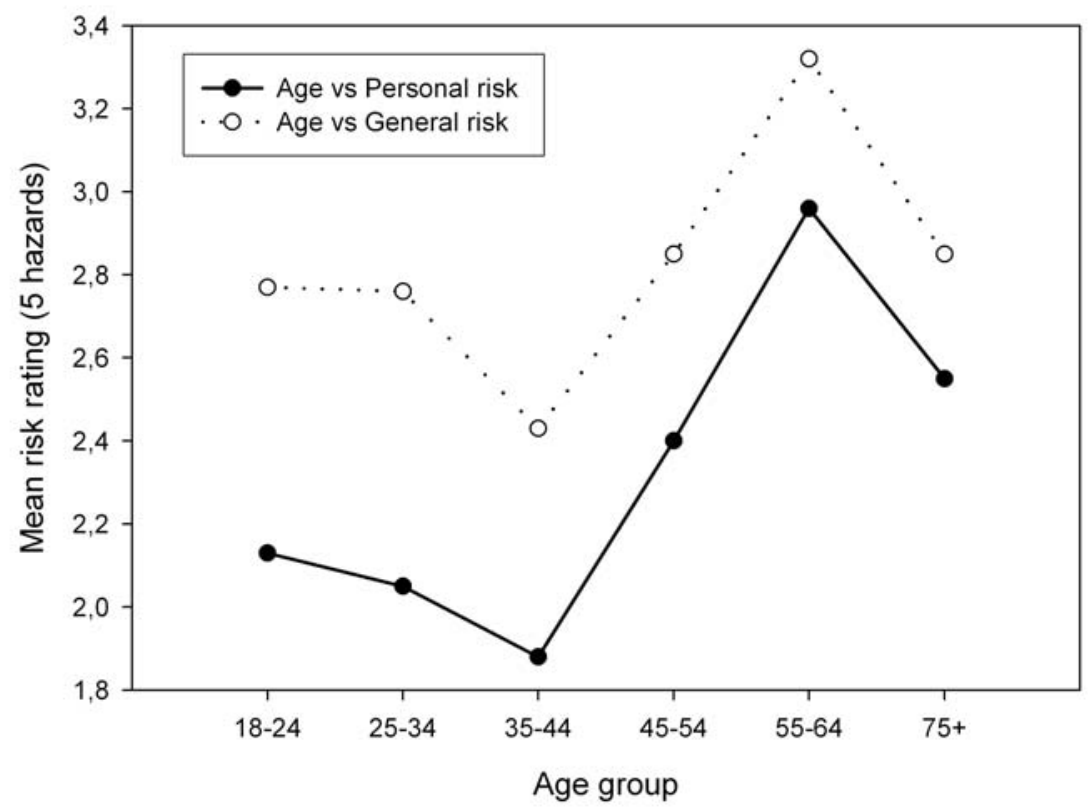

Fig. 2. Age differences, personal and general terrorism risk

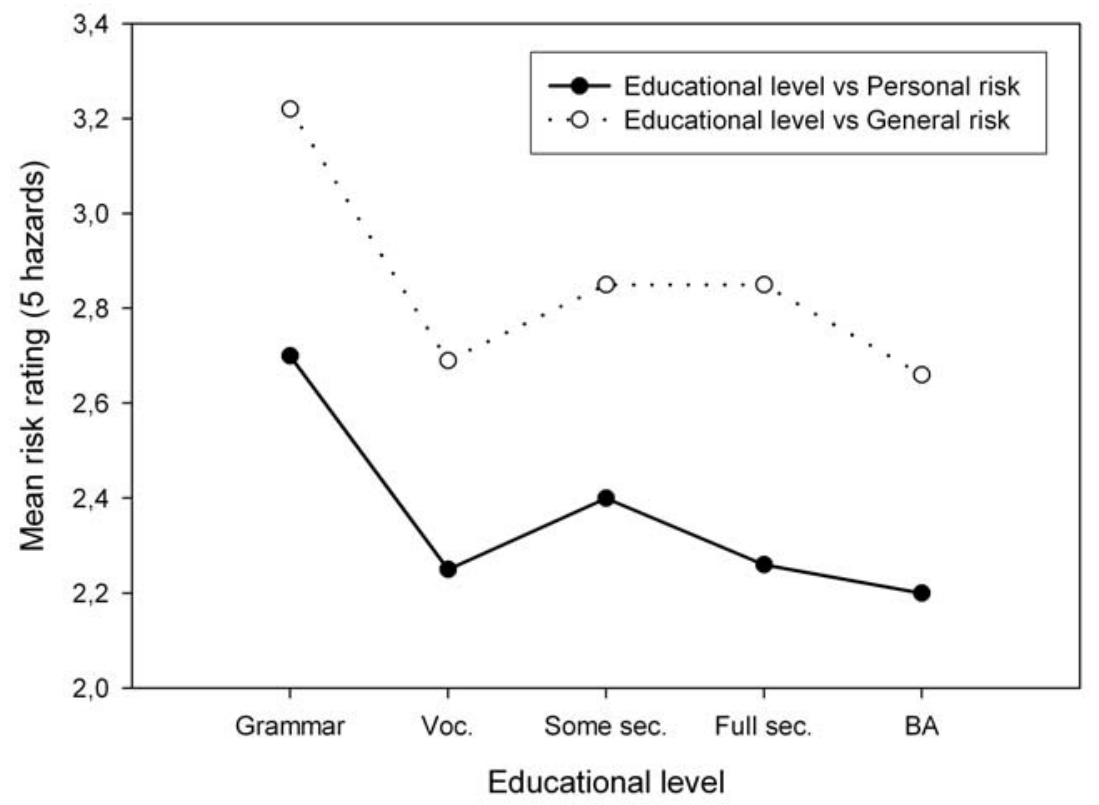

Fig. 3. Differences among educational levels, personal and general terrorism risk

These results are in good agreement with other research on background data and risk perception. Note, again, the clear difference between personal and general risk, which suggests that the terrorism threat is seen as one over which the respondents have some degree of control and possibility of protection (Sjöberg, 2000a). 
The response distributions to each of the 15 items measuring suspicious thought patterns are provided in Table 2.

\section{Table 2. Distribution of responses (percentage) to items measuring beliefs about} subversion, manipulation and control

\begin{tabular}{|c|c|c|c|c|c|}
\hline Item & $\begin{array}{c}\text { Agree } \\
\text { absolu } \\
\text {-tely }\end{array}$ & $\begin{array}{l}\text { Agree } \\
\text { on the } \\
\text { whole }\end{array}$ & $\begin{array}{l}\text { Doubt } \\
\text {-ful }\end{array}$ & $\begin{array}{l}\text { Dis- } \\
\text { agree } \\
\text { on the } \\
\text { whole }\end{array}$ & $\begin{array}{l}\text { Dis- } \\
\text { agree } \\
\text { abso- } \\
\text { lutely }\end{array}$ \\
\hline $\begin{array}{l}\text { Many very important things happen in the world, that } \\
\text { the public is never informed about }\end{array}$ & 32.0 & 46.7 & 14.8 & 5.5 & 1.0 \\
\hline $\begin{array}{l}\text { I think that we now face a time of great risks for war } \\
\text { and violence }\end{array}$ & 15.1 & 44.0 & 31.6 & 7.6 & 1.7 \\
\hline $\begin{array}{l}\text { There are probably many more groups that are planning } \\
\text { attacks than media have reported }\end{array}$ & 25.5 & 50.0 & 21.4 & 2.8 & 0.3 \\
\hline $\begin{array}{l}\text { I have thought about the risk of contamination from } \\
\text { opening letters, e.g. from the USA }\end{array}$ & 4.8 & 15.5 & 29.7 & 26.9 & 23.1 \\
\hline $\begin{array}{l}\text { Events that superficially seem to lack a connection are } \\
\text { often the result of secret activities }\end{array}$ & 9.0 & 42.7 & 37.2 & 9.4 & 1.7 \\
\hline $\begin{array}{l}\text { I believe that e-mail in this country sometimes is read } \\
\text { by American government agencies such as the FBI or } \\
\text { CIA, without our knowing about it }\end{array}$ & 11.0 & 19.2 & 39.9 & 14.4 & 15.5 \\
\hline $\begin{array}{l}\text { So-called subliminal advertising (ads being shown so } \\
\text { fast that we do not have time to notice) probably exists } \\
\text { and influence people to a large extent }\end{array}$ & 12.4 & 32.8 & 34.1 & 12.8 & 7.9 \\
\hline $\begin{array}{l}\text { The government agencies in Sweden monitor closely all } \\
\text { citizens }\end{array}$ & 10.7 & 24.5 & 29.3 & 18.6 & 6.9 \\
\hline $\begin{array}{l}\text { There are a great many data bases that I do not know } \\
\text { about and that contain important information about me }\end{array}$ & 22.1 & 41.4 & 22.8 & 9.0 & 4.8 \\
\hline I often feel that surveillance cameras are registering me & 2.4 & 9.3 & 22.1 & 33.8 & 32.4 \\
\hline $\begin{array}{l}\text { Telephone wire tapping is probably more common than } \\
\text { what many people believe }\end{array}$ & 6.5 & 16.5 & 36.1 & 25.8 & 15.1 \\
\hline $\begin{array}{l}\text { Public service TV and radio are trying to influence the } \\
\text { public's political opinions }\end{array}$ & 11.4 & 25.9 & 30.3 & 20.3 & 12.1 \\
\hline $\begin{array}{l}\text { The government can find out how I voted in } \\
\text { parliamentary elections }\end{array}$ & 5.2 & 10.0 & 35.1 & 14.8 & 35.1 \\
\hline $\begin{array}{l}\text { If I borrow books in a public library there is a risk that } \\
\text { my interests are reported, e.g. to the security police }\end{array}$ & 1.7 & 8.6 & 30.2 & 23.7 & 35.7 \\
\hline $\begin{array}{l}\text { I have sometimes noted that somebody has } \\
\text { surreptitiously opened my mail }\end{array}$ & 1.0 & 2.1 & 7.6 & 16.8 & 72.5 \\
\hline
\end{tabular}


Beliefs varied widely, but in some cases they were surprisingly strong. About 30 percent indicated that they thought Swedish e-mail was sometimes secretly read by American government agencies. As many as 15 percent believed that the government could find out how they voted in Parliamentary elections - a high figure since secret voting is one of the cornerstones of Swedish democracy. A large majority (about 75 percent) thought there are many terrorist groups planning new attacks that were never reported by the media. About half believed that there were secret links between events that seem superficially to be unrelated. Some 20 percent had worried about illness from letter contamination, and so on.

As noted in the Methods section, these beliefs reflected an underlying, one-dimensional thought pattern of suspiciousness.

\section{Regression models of perceived terrorism risk}

Correlations between perceived risk (four variables) and other scales are given in Table 3.

The risk variables were combined measures of personal and general terrorism risks, Imminent risk (based on the WTC items) and Societal threat (based on threat items).

\begin{tabular}{|c|c|c|c|c|}
\hline & & & Imminent & Societal \\
\hline & Personal risk & General risk & risk & threat \\
\hline Gender & $0.15^{*}$ & $0.22 *$ & 0.00 & 0.10 \\
\hline Age & $0.15^{*}$ & 0.09 & 0.08 & $0.20 * *$ \\
\hline Educational level & 0.09 & 0.09 & $-0.22 * *$ & $-0.15^{*}$ \\
\hline Dread & $0.33 * *$ & $0.31 * *$ & $0.43 * *$ & $0.37 * *$ \\
\hline New risk & 0.03 & 0.08 & 0.08 & 0.06 \\
\hline Crime as a cause of risk & $0.37 * *$ & $0.37 * *$ & $0.43 * *$ & $0.36^{* *}$ \\
\hline Selfishness as a cause of risk & $0.20 * *$ & $0.17 * *$ & $0.39 * *$ & $0.24 * *$ \\
\hline "Injustice" as a cause of risk & 0.03 & 0.1 & 0.04 & 0.04 \\
\hline Competence of perpetrators & 0.05 & 0.12 & $0.35^{* *}$ & $0.13 *$ \\
\hline $\begin{array}{l}\text { Perpetrators confused and } \\
\text { ignorant }\end{array}$ & $0.23 * *$ & $0.29 * *$ & $0.33 * *$ & $0.24 * *$ \\
\hline Suspicious thought patterns & $0.32 * *$ & $0.32 * *$ & $0.51^{* *}$ & $0.33 * *$ \\
\hline
\end{tabular}


The table shows:

! Gender, age and educational level were related to perceived risk, but not strongly or consistently.

! Dread was strongly and consistently related to perceived risk, but New Risk was not.

! Reasons for riskiness were strongly and consistently related to perceived risk, especially crime as a source of risk.

! The characteristics of perpetrators were related to perceived risk, but competence less so than conceiving the perpetrators as confused or misinformed about the modern world.

! Suspicious thought patterns were consistently and strongly related to perceived risk of terrorism.

Four regression models were run, for personal risk (combined 5 terrorism hazards), general risk (same combined hazards), for the factor Imminent risk of new attacks, based on the WTC items, and for terrorism as a threat to society ${ }^{9}$. See Table 4.

The results show only small effects only of background data in terms of $\mathrm{R}^{2}$ adj (squared multiple correlation, or variance accounted for, adjusted for degrees of freedom) for that block (educational level, gender, age) separately.

\section{Table 4. Variance of perceived risk of terrorism accounted for by various sets of explanatory constructs}

\begin{tabular}{|l|l|l|l|l|}
\hline & \multicolumn{2}{|l|}{$\mathrm{R}_{\text {adj }}^{2}$} \\
& $\begin{array}{l}\text { Personal } \\
\text { risk }\end{array}$ & $\begin{array}{l}\text { General } \\
\text { risk }\end{array}$ & $\begin{array}{l}\text { Immi- } \\
\text { nent risk }\end{array}$ & $\begin{array}{l}\text { Threat to } \\
\text { society }\end{array}$ \\
\hline Block 1: background data & 0.041 & 0.054 & 0.038 & 0.049 \\
Block 2: Dread and New Risk & 0.102 & 0.089 & 0.180 & 0.131 \\
Block 1+2 & 0.119 & 0.110 & 0.199 & 0.154 \\
Block 3: Suspicious Thought Patterns, & 0.160 & 0.166 & 0.328 & 0.164 \\
Reasons for a Risky World & 0.224 & 0.226 & 0.412 & 0.250 \\
Block 1+2+3 & 0.036 & 0.077 & 0.195 & 0.059 \\
Block 4: Characteristics of perpetrators & 0.221 & 0.233 & 0.452 & 0.248 \\
All blocks & & & & \\
\hline
\end{tabular}

9. Imminent risk was treated as a dependent variable since these items were semantically close to the perceived size of the risk. Using them as an explanatory factor for modelling other risk perception items increased the level of explained variance with about 5 percent. 
The table also shows that ratings of risk were harder to account for than Likert type attitude statements expressing risk. A similar result was found with regard to trust as expressed in ratings or as responses to typical attitude items (Sjöberg, 2002b).

It is interesting to see that Suspicious Thought Patterns and Reasons for a Risky world was the most efficient block of explanatory constructs and that background data and the two Psychometric Model dimensions (New Risk and Dread) added something, but only about 510 percent explained variance. The views concerning the attack itself and the perpetrators added very little to the perceived risk, in the linear regression models.

As noted above, the dimension measuring apologetic reasons for terrorism in terms of "global injustice" did not correlate with perceived risk. The reason is a non-linear relationship, see Fig. 4. A trend analysis of the relationship gave an F-value of 1.736 for the quadratic term, $\mathrm{p}=0.189, \mathrm{df}=1,285$.

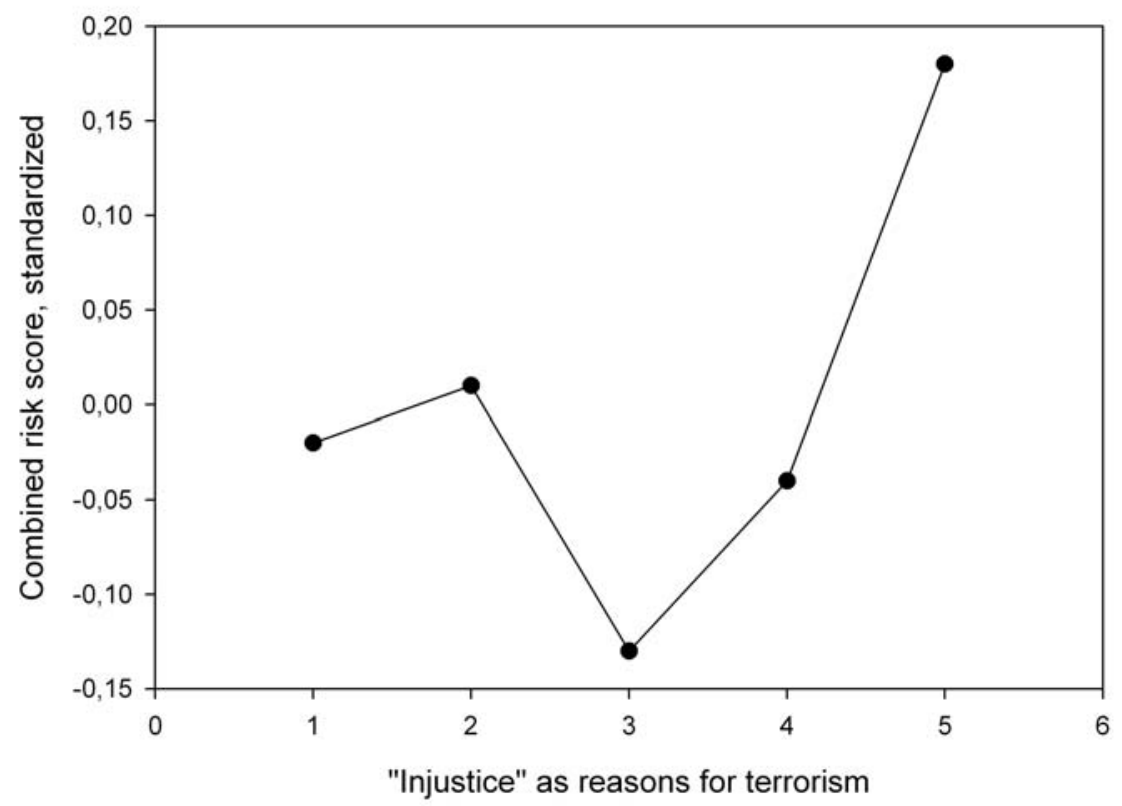

Fig. 4. Risk perception of terrorism vs. reasons in "global injustice".

People who were strongly convinced of "injustice" as an explanation also tended to see the risk as large, but so did those who rejected this particular theory of terrorism, relatively speaking. The hesitant group perceived the smallest risk.

Generalization of risks. One index based on items directly concerned with the 9/11 events was that of imminent risk. This scale measures beliefs about new terrorist actions coming up in the near future. Three further items measured similar beliefs, viz. 
! I think we are now facing a time with large risks of war and violence.

! There are probably many more groups planning attacks than what has been revealed by media.

! I have considered the risk of contamination with illness from opening letters, e.g. from the USA

These items were correlated with the four risk indices, see Table 5

\section{Table 5. Correlations between risk indices and variables measuring conceptions of spreading and imminent risks of terrorism.}

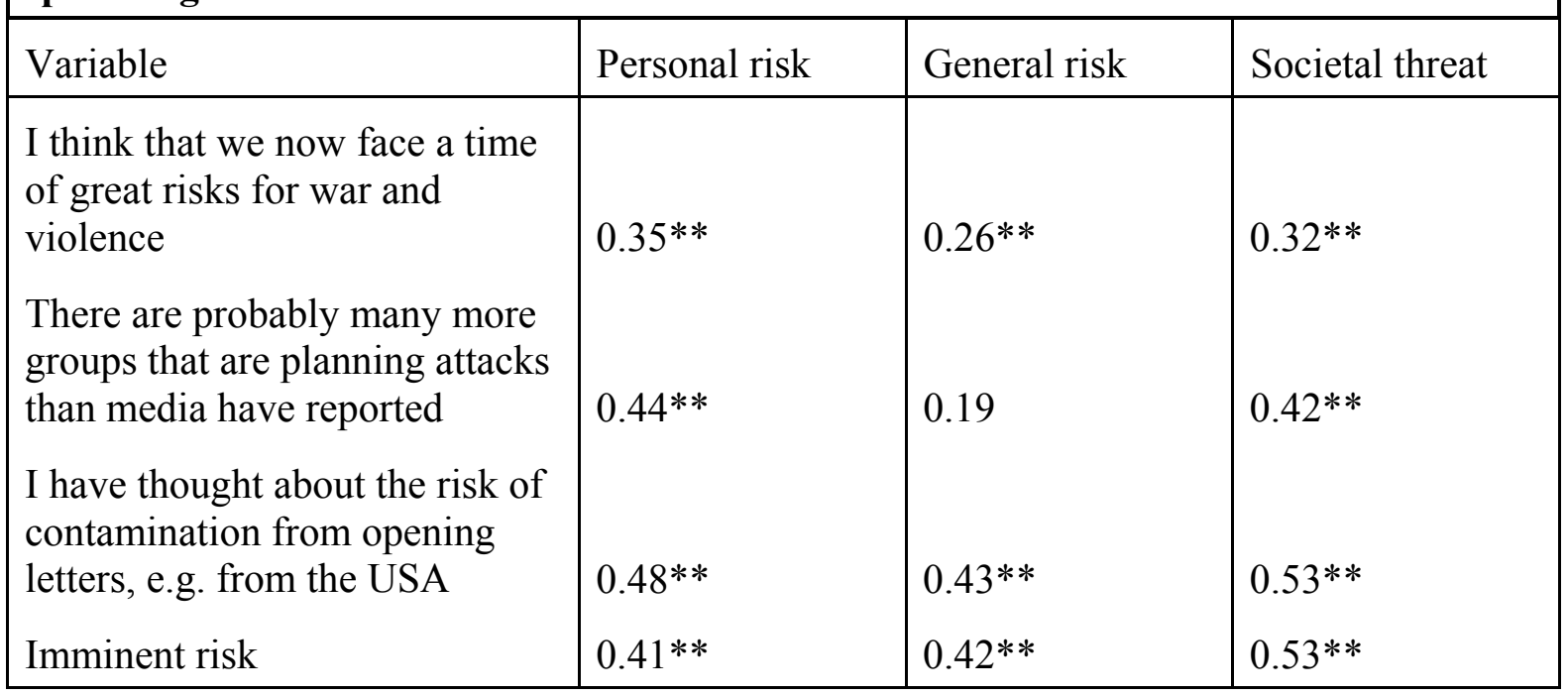

$* \mathrm{p}<0.05$

$* * \mathrm{p}<0.01$

It was found the perceived risk was strongly correlated with the items measuring spread of risk and future risk. The perspective of risk generalization hence seemed to be quite prominent, see also Table 2.

\section{Discussion}

The present data from the summer of 2002 showed a relatively low level of concern over terrorism, in contrast to the elevated levels of the fall of 2001. A tapering off of concern has been found in several opinion polls but new events can of course lead to another increase of worry. Similar trends have been observed after other disasters, such as the Chernobyl accident in 1986 (Sjöberg \& Drottz, 1987).

The purpose of the present study was to enhance our understanding of the factors in the perceived risk of terrorism. The traditional Psychometric Model is an attempt to relate perceived risk to characteristics of hazards, but it was in the present case rather little successful. It is true that the concept of New Risk was not measured very reliably. Yet, other work on New Risk has also failed to confirm its importance in accounting for interindividual variation in risk perception (Sjöberg, in press-b). 
Findings on demographic factors were similar to those of Fischhoff et al. (Fischhoff et al., 2003). They also noted the difference between personal and general risk. In future work, it is important to investigate the control dimension. A large difference between personal and general risk suggests that people perceive a high degree of control (Harris, 1996). Why should that be the case with regard to terrorism? It should also be noted that in a case with distinctly larger general than personal risk one would expect that policy attitudes, such as the demand for government action, is more strongly related to general than personal risk (Sjöberg, 2003a).

The explanatory value of the dimensions devised in the present study was promising but much remains to be explained of how people perceive the terrorism risk. It may be noted that risk perception with regard to technology and environment risks can readily be explained to about 60 percent (Sjöberg, 2000b, 2000c). One factor not attempted here, but usually important in the study of technology risks, is that of over-all attitude. It would be interesting to see if a corresponding dimension is of importance also in the present case. Trust is another factor of importance in current work on risk perception (Slovic, Flynn, \& Layman, 1991). Trust in those responsible for managing terrorism threats could be brought into the study of perceived terrorism risks, taking also the genuine uncertainty of how to assess those risks into account (Sjöberg, 2001).

It is interesting to note that both specific and general thinking about the nature of terrorist acts and subversion played an important role in accounting for perceived risks and threats. Considerable improvement in understanding of perceived risk of terrorism was achieved by bringing in data on the wider context of thoughts about these hazards. General suspiciousness was one important factor, and other factors were based on causal thought about risk and the specific nature of the $9 / 11$ events. The perceived competence of the perpetrators was less important, however. Beliefs implying a view of them as confused and out of touch with the modern world were more important. It is possible that views on criminals may exhibit the same distinction - efficient and "rational" criminals on the one hand, confused or fanatical persons on the other. Maybe there is reason to fear the second type of criminal more than the first.

It is also noteworthy that the emergent apologetic theory of terrorism, seeing it as a "regrettable but understandable" response to injustice in the world, had no clear linear relationship to perceived risk. People who held strong views regarding this "theory" saw the risks as larger, whether they subscribed to it or rejected it. This may, in turn, be a special case of the finding that people who were more certain of causes of risks also saw the risks as larger. This finding needs to be replicated on new data since it did not reach a conventional level of statistical significance. 


\section{References}

Bennulf, M. (2002). Opinion 2001. Nya hot och risker. Stockholm: Styrelsen för psykologiskt försvar.

Durodié, B., \& Wessely, S. (2002). Resilience or panic? The public and terrorist attack. The Lancet, 360, 1901-1902.

European Commission. (2002). Standard Eurobarometer 56. Brussels: European Commission.

Fischhoff, B., Gonzalez, R. M., Small, D. A., \& Lerner, J. S. (2003). Judged terror risk and proximity to the World Trade Center. Journal of Risk and Uncertainty, 26, 137-151.

Fischhoff, B., Slovic, P., Lichtenstein, S., Read, S., \& Combs, B. (1978). How safe is safe enough? A psychometric study of attitudes towards technological risks and benefits. Policy Sciences, 9, 127-152.

Forskningsgruppen för Samhälls- och Informationsstudier. (2002). Meddelande 2002.12.13.

Galea, S., Ahern, J., Resnick, H., Kilpatrick, D., Bucuvalas, M., Gold, J., \& Vlahov, D. (2002). Psychological sequelae of the September 11 terrorist attacks in New York City. New England Journal of Medicine, 346, 982-987.

Gallup. (2002). Terrorism in the United States. Poll Topics and Trends.

Gardner, G. T., \& Gould, L. C. (1989). Public perceptions of the risk and benefits of technology. Risk Analysis, 9, 225-242.

Gillespie, M. (2002). Public confident in security of airline travel. New federal role in airport security expected to help. Gallup Report.

Halpern-Felsher, B. L., \& Millstein, S. G. (2002). The effects of terrorism on teens' perceptions of dying: the new world is riskier than ever. Journal of Adolescent Health, 30, 308-311.

Harris, P. (1996). Sufficient grounds for optimism?: The relationship between perceived controllability and optimistic bias. Journal of Social and Clinical Psychology, 15, 9-52.

Holmberg, S., \& Weibull, L. (Eds.). (2002). Det våras för politiken. Göteborg: Göteborgs universitet.

Kasperson, R. E. (1992). The social amplification of risk: progress in developing an integrative framework. In S. Krimsky \& D. Golding (Eds.), Social theories of risk (pp. 153-178). Westport: Praeger.

Kasperson, R. E., Renn, O., Slovic, P., Brown, H. S., Emel, J., Goble, R., Kasperson, J. X., \& Ratick, S. (1988). The social amplification of risk. Risk Analysis, 8, 177-187.

Katz, C. L., Pellegrino, L., Pandy, A., Ng, A., \& DeLisi, L. E. (2002). Research on psychiatric outcomes and interventions subsequent to disasters: a review of the literature. Psychiatry Research, 110, 201-217.

Lerner, J. S., Gonzalez, R. M., Small, D. A., \& Fischhoff, B. (2003). Effects of fear and anger on perceived risks of terrorism: A national field experiment. Psychological Science, 14, 144-150.

Lindkvist, T., Österman, T., \& Timander, J. (2002). Om framtida hotbilder (FSI-rapport 2002: v20hot). Stockholm: Forskningsgruppen för Samhälls- och Informationsstudier. 
Marris, C., Langford, I., Saunderson, T., \& O'Riordan, T. (1997). Exploring the "psychometric paradigm": Comparisons between aggregate and individual analyses. Risk Analysis, 17, 303-312.

Poortinga, W., \& Pidgeon, N. F. (2003). Exploring the dimensionality of trust in risk regulation. Risk Analysis, 23, 961-972.

Rawlings, D., \& Freeman, J. L. (1996). A questionnaire for the measurement of paranoia/suspiciousness. British Journal of Clinical Psychology, 35, 451-461.

Renn, O., Burns, W., Kasperson, R. E., Kasperson, J. X., \& Slovic, P. (1992). The social amplification of risk: Theoretical foundations and empirical application. Journal of Social Issues, 48, 137-160.

Saad, L. (2003). POLL ANALYSES, February 25, 2003. Public Relieved About Terrorism as "Orange" Alert Drags On. The Gallup Organization.

Schlenger, W. E., Caddell, J. M., Ebert, L., Jordan, B. K., Rourke, K. M., Wilson, D., Thalji, L., Dennis, J. M., Fairbank, J. A., \& Kulka, R. A. (2002). Psychological reactions to terrorist attacks: Findings from the National Study of Americans' Reactions to September 11. JAMA: Journal of the American Medical Association, 288, 581-588.

Sellers, K. G. (2002). The perception of risk. Catalyst, 18-22.

Silver, R. C., Holman, E. A., McIntosh, D. N., Poulin, M., \& Gil-Rivas, V. (2002). Nationwide longitudinal study of psychological responses to September 11. JAMA: Journal of the American Medical Association, 288, 1235-1244.

Sjöberg, L. (1996). A discussion of the limitations of the psychometric and Cultural Theory approaches to risk perception. Radiation Protection Dosimetry, 68, 219225.

Sjöberg, L. (2000a). The different dynamics of personal and general risk. In M. P. Cottam \& D. W. Harvey \& R. P. Pape \& J. Tait (Eds.), Foresight and precaution. Volume 1 (pp. 1149-1155). Rotterdam: A. A. Balkema.

Sjöberg, L. (2000b). Factors in risk perception. Risk Analysis, 20, 1-11.

Sjöberg, L. (2000c). Specifying factors in radiation risk perception. Scandinavian Journal of Psychology, 41, 169-174.

Sjöberg, L. (2001). Limits of knowledge and the limited importance of trust. Risk Analysis, 21, 189-198.

Sjöberg, L. (2002a). Are received risk perception models alive and well? Risk Analysis, $22,665-670$.

Sjöberg, L. (2002b). Attitudes to technology and risk: Going beyond what is immediately given. Policy Sciences, 35, 379-400.

Sjöberg, L. (2003a). The different dynamics of personal and general risk. Risk Management: An International Journal, 5, 19-34.

Sjöberg, L. (2003b). The polling of risk and worry. Unpublished manuscript.

Sjöberg, L. (in press-a). Explaining individual risk perception: the case of nuclear waste. Risk Management: An International Journal.

Sjöberg, L. (in press-b). Local acceptance of a high-level nuclear waste repository. Risk Analysis.

Sjöberg, L. (submitted). Rational risk perception: Utopia or dystopia?

Sjöberg, L., \& Drottz, B.-M. (1987). Psychological reactions to cancer risks after the Chernobyl accident. Medical Oncology and Tumor Pharmacotherapy, 4, 259-271.

Sjöberg, L., \& Drottz-Sjöberg, B.-M. (1991). Knowledge and perception of risk among nuclear power plant employees. Risk Analysis, 11, 607-618.

Slovic, P., Flynn, J. H., \& Layman, M. (1991). Perceived risk, trust, and the politics of nuclear waste. Science, 254, 1603-1607. 
Stütz, G. (2002). Opinion 2002 - Den svenska allmänhetens syn på samhället, säkerhetspolitiken och försvaret hösten 2002 (Meddelande 162). Stockholm: Styrelsen för psykologiskt försvar.

Sunstein, C. R. (2003). Terrorism and probability neglect. Journal of Risk and Uncertainty, 26, 121-136.

The Gallup Organization. (2003). Worry about terrorism increases. Poll Analyses.

Viscusi, W. K., \& Zeckhauser, R. J. (2003). Sacrificing civil liberties to reduce terrorism risks. Journal of Risk and Uncertainty, 26, 99-120. 